DOI: https://doi.org/10.47405/mjssh.v7i1.1241

\begin{tabular}{|c|c|}
\hline 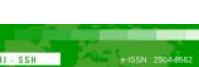 & Malaysian Journal of Social Sciences and Humanities (MJSSH) \\
\hline Malaysian Journal of & Volume 7, Issue 1, January 2022 \\
\hline $\begin{array}{l}\text { Humantites } \\
\text { (MJ-sSH) }\end{array}$ & e-ISSN : 2504-8562 \\
\hline & $\begin{array}{l}\text { Journal home page: } \\
\text { www.msocialsciences.com }\end{array}$ \\
\hline
\end{tabular}

\title{
Factors Influencing the Choice of Music Studies in Malaysian Public Universities
}

\author{
Fatin Hani Mohd Sheriff' ${ }^{1}$, Pan Kok Chang1 \\ 1Faculty of Creative Arts, University of Malaya, Kuala Lumpur, Malaysia \\ Correspondence: Fatin Hani Mohd Sheriff (fatinhani@siswa.um.edu.my)
}

\begin{abstract}
Introducing music in the early childhood can help influence students to have a positive attitude in pursuing music in a higher level of education. Examining the developmental aspects of the decision to continue music studies among undergraduate music students is necessary in order to determine which factors had the most influences. This study investigates factors influencing choice of music studies among undergraduate music students in Malaysian public universities namely institutional factors, academic factors, financial factors, and personal/social factors. A survey method was adopted, and 489 respondents were chosen using proportionate stratified random sampling to answer the questionnaire. Data were analysed using the Statistical Package for the Social Sciences (SPSS). The finding showed that academic factors was ranked as the most influential factor on choice of music studies among music students. The results on inferential statistical analysis using independent-samples $t$-test and the OneWay Analysis of Variance (ANOVA) test showed that there were significant differences on factors influencing choice of music studies between ethnicities, universities attended, and instruments played. It is hoped that the findings will be beneficial to students, educators, and the university music programmes. Educators will also have access to the most up-to-date information in order to come up with strategies in encouraging students to study music.
\end{abstract}

Keywords: Music studies, academic factors, institutional factors, financial factors, personal/social factors

\section{Introduction}

Students' participation in music during their early school years has bring benefits in terms of their spiritual, physical and psychological development. However, music education in Malaysia is often considered as optional (Nor, 2011). The study in this research has gathered music students from different ethnicities and religions in Malaysia. Three major ethnic groups are defined as the Malays, Chinese and Indian races, which equals to culturally diversified backgrounds. The Malays, Orang Asli (the indigenous groups of peninsular Malaysia) and the people of Borneo Island in East Malaysia which are the natives of Sabah and Sarawak (Iban, Bidayuh, Melanau, Kadazan-dusun etc.) are known as Bumiputera. The Chinese and Indian people are categorised under the Non-Bumiputera.

Previous research has revealed that music education can develop potentials in a student's character, hence shaping them to be quality students with good personality. Students who started their formal music education during primary or secondary school mostly experience enjoyment, personal musical success and love for music. As stated by McClellan (2007), students' involvements in wide variety of 
musical experiences lead to the decision to apply to music programmes in university and pursue a degree in music. Overmier (2003) conducted a study to identify and recognise the choices of freshman music majors. According to the researcher, there are five important factors that influenced undergraduate music majors which are the department's reputation, the availability of course that is offered in the university, individual involvement with the faculty, tuition expenses, and parents. Nevertheless, studies by Kelly (1988) and Overmier (2003) found that campus activities have also been very influential in the sense of personal interaction with the institution. Recognition, fraternities, recommendation from their high school music teacher, the distance from their home to the institution, and a family member attending the same institution can be considered as the least important factors. Five most well-known enrollment techniques used by faculty were recorded by Overmier (2003). The techniques are form letters, the use of pamphlet in the department, grant offer, an encouragement to visit the faculty and individual letters to invite the students to be part of the institution. The results in his study showed that the most effective enrollment techniques employed by faculty was the grant offer. Form letters such as list of programmes and department brochures or pamphlets have shown ineffective results in the enrollment techniques. Therefore, it cannot be seen as a contributing factor to the decision-making to pursue music in university.

Curtis (2012) cited the earliest study in the field of institutional preferences of undergraduate music students from Ludeman (1964). In the study, it was found that there are several persuasive elements in the determination of entering the university or college experienced by undergraduate music students which are excellent music institution, high expectations, a well-balanced music programmes, remarkable performing ensembles, and studying music with top institutional representatives in the field. After almost two decades, Locke (1982) studied the same characteristics on factors influencing undergraduate music students on college choice in Illinois. In the study, the researcher listed 10 most influential factors which are: overall reputation of the music faculty, the pleasure to commute from home to university, friendliness from the institution representatives, proximity to home, advantage to perform with outstanding groups, best deal of institution fees, availability of the specific degree programmes, credibility of the group performer at the desired institution, and the overall performance of the school.

However, these findings do not automatically provide a clear view of the factors influencing Malaysian undergraduate music students since they were not conducted in Malaysia. Despite the available literature to the researchers' knowledge, little to no research has been able to give a comprehensive picture of factors influencing the choice of music studies among undergraduate music students in Malaysian public universities.

\section{Literature Review}

Few researchers have discussed what influenced students in their decision-making when entering higher education institution (Bright, 2006; Hamilton, 2016; Gillespie \& Hamann, 1999; McClellan, 2011; McClellan, 2007; Sichivitsa, 2007). However, the influence on students majoring in music has not been widely researched (Madsen \& Kelly, 2002; Lindamen, 2004; Curtis, 2012). Constantine (2011) did study the external and internal factors that affect students' enrolment in music high school. As a result, numerous justifications were found on why students choose to enrol in music school. Things outside of the student's power and control like class schedules, socioeconomic status, family and parents, teachers as well as friends are considered as the external factors. Internal factors, on the other hand, can include social identity, inner motivation, attitude, attribution, self-concept as well as expectancy value.

Observing effective teaching as an educator could also influence and captivate future music students. Thornton and Bergee (2008) studied 242 students major in music education at 12 selected schools with National Association of Schools of Music (NASM) accreditation to identify factors that influence students' decisions to join music education. Results showed that the influence of music teachers, love of music, love of teaching, ensemble experiences, and the desire to share music with students were the most important factors in choosing a career in music education. 
It is clear that students have many decisions to make as well as other influences to consider when they choose to pursue a degree in music studies upon completing secondary education. Curtis (2012) identified four factors that influence students to choose music as their major study namely academic, institutional, financial and personal/social. Eighty-four respondents completed the survey from two public and private universities in Missouri and Illinois. Results from the study indicated that academic influences for both public and private institutions can impact college music students. It was found that the location of the university was shown to be the most influential factors, followed by the class size. Funding sources, particularly in terms of scholarship, was rated to have very high influence by the music students. According to the survey, offering a scholarship has earned the most favourable responses from all universities. Nevertheless, most universities regarded personal/social factors as minor determinants of choice. Curtis (2012) found that music students did not use social media to choose their institution, however, when students were analysed by faculty/departments, social factors had a modestly positive response towards college choice.

Previous studies on music education by Klinedinst (1991) and Mizener (1993) have claimed that the attitudes possessed by students towards music are usually related to their experiences and activities in the musical field at home and school. One of the latest studies, Yoo (2020) has reviewed the factors influencing future music participation based on the Theory of Planned Behaviour. He revealed that there are several reasons that inspire students to pursue musical education and activities. Focusing on the factors that affect youth and their idea in getting involved with activities related to music, the study found that there are four constructs of TPB which include attitude toward behaviour, perceived behaviour control, subjective norms, and other factors. Yoo (2020) also added that there are relationships on the attitude toward behaviour and normative factors. Family members, educators, and peers also play a big role in shaping an individual's attitudes toward music, hence resulting in the possibility of the person to participate in music study in the future.

Students may encounter motivational factors and influences when choosing music studies. McCarthy, O'Flaherty and Downey (2019) studied the attitudes that students in the Republic of Ireland have against the music subject in secondary education. Using qualitative approach, data collection was carried using interviews and focus groups. Throughout the findings, McCarthy et al. (2019) found that the attitudes the students have towards music were affected by several factors. First up is their inner passion and interest for music, supported by their talent and capabilities in the field. Following that is the future possibilities of their tertiary education or career where music is viewed as one of the pathways they can walk on. Results from the study also revealed that students' attitude were affected by the syllabus of the music subject and the teaching method of their educators.

\section{Objectives of the Study}

The objectives of the study are:

1. To examine the perceptions on factors influencing students' choice of music studies (academic factors, institutional factors, financial factors, and personal/ social factors) in the universities.

2. To measure differences on factors influencing students' choice of music studies with selected demographic profiles (universities, instruments played, and ethnicities).

\section{Methodology}

This study adopted a survey method to collect data. The target population involves seven Malaysian public universities that offer music courses which are Universiti Teknologi MARA (UiTM), Universiti Putra Malaysia (UPM), Universiti Malaya (UM), Universiti Pendidikan Sultan Idris (UPSI), Universiti Sains Malaysia (USM), Universiti Malaysia Sarawak (UNIMAS), and Universiti Malaysia Sabah (UMS). The study had chosen undergraduate music students and was conducted from September 2019 to February 2020. Using proportionate stratified random sampling technique, 489 students from the 
seven universities had responded to the questionnaire in the study. The questionnaire was assigned randomly to the respondents to reduce biasness.

The questionnaire was adapted from Curtis (2012) and revised by the researcher to help the students understand the questions on music studies. The questionnaire consisted of twenty-two (22) statements based on various factors namely academic, institutional, financial, and personal/social using a Likerttype scale of 1 to 5 . Students were required to indicate their answer by ticking after each statement under the columns from 1 to 5: (1) Strongly Disagree; (2) Disagree; (3) Neutral; (4) Agree; and (5) Strongly Agree. Using the Statistical Package for the Social Sciences (SPSS), descriptive analyses using percentages, means and standard deviation were used and inferential statistics using the independent samples $t$-test and One-Way Analysis of Variance (ANOVA) test were employed.

\section{Results and Discussions}

\section{Demographic information of the respondents}

Results on demographic information of the respondents who had participated in the study shows that most of the respondents are female $(n=302$ or $61.8 \%)$ and the balance are male $(n=187$ or $38.2 \%)$. Most of the respondents are from UPSI $(n=107$ or $21.9 \%)$. This is followed by those in UiTM $(n=85$ or $17.4 \%)$ and UNIMAS ( $n=78$ or $16 \%$ ). UMS, UPM and UM have the same number of respondents which are $60(12.3 \%)$, whilst USM has the lowest percentage at only 39 or $8 \%$ of the respondents. Majority of the respondents are Malaysian Chinese (34.3\%) whilst 32.2\% of the respondents are Malays. Respondents from Bumiputera Sabah such as Kadazan, Dusun, Bajau and Murut amounted to 23.9\%, followed by the Bumiputera Sarawak that comprised of Bidayuh, Iban and Melanau (7.6\%), and the least are Indians with only $2 \%$. In terms of ethnicities, majority are from the Bumiputera $(n=$ 311 or $63.7 \%)$ while the Non-Bumiputera at $178(36.3 \%)$. Most of the respondents played piano $(n=$ 171 or $35 \%)$ and the smallest group played brass instruments $(n=20$ or $4 \%)$.

\section{Perceptions on Academic Factors}

Table 1 presents the mean scores of the statements used to measure the perceptions of the respondents on academic factors and its related statistics. Based on all the six statements, the overall mean score is 3.67 , implying that on the average, the respondents almost agree (mean $=3.67$ ) with the statements about academic factors.

Table 1: Mean and SD on Academic Factors

\begin{tabular}{|c|c|c|}
\hline Statement & Mean & SD \\
\hline $\begin{array}{l}\text { Quality of the music faculty at the university influenced me to } \\
\text { study music }\end{array}$ & 3.75 & 0.932 \\
\hline Course offerings of the university influenced me to study music & 3.73 & 0.935 \\
\hline $\begin{array}{l}\text { Types of university (e.g. public vs. private) influenced my } \\
\text { decision to attend the university }\end{array}$ & 3.72 & 0.951 \\
\hline Reputation of the university influenced me to study music & 3.67 & 0.950 \\
\hline $\begin{array}{l}\text { Success of previous graduates at the university influenced me to } \\
\text { study music }\end{array}$ & 3.63 & 1.030 \\
\hline $\begin{array}{l}\text { Admission requirements of the university influenced me to study } \\
\text { music }\end{array}$ & 3.52 & 1.008 \\
\hline Academic Factors & 3.67 & 0.711 \\
\hline
\end{tabular}

$n=489$

In particular, the quality of the music faculty at the university influenced most of the respondents to study music as indicated with the high mean score (3.75). This is followed by the course offered by the university and types of university (e.g. public vs. private) (mean $=3.73$ and 3.72 ) respectively. On the 
other hand, the mean for reputation of the university (mean $=3.67$ ) and success of previous graduates at the university (mean $=3.63$ ) are relatively lower than the above academic factors, with the lowest being the admission requirements of the university (mean = 3.52). Across the six (6) factors, the involvement is consistent as portrayed by the range in standard deviations values relative to the mean score values.

\section{Perceptions on Institutional Factors}

Institutional factors scored an overall mean of 3.47 in Table 2, indicating that on average, institutional factors influence the choice of music studies moderately. Among the 6 statements, respondents are relatively most likely to be influenced by the location of the university (mean $=3.57$ ). This is followed by, in descending order, the facilities at the university (mean $=3.55$ ), campus atmosphere (mean $=$ 3.54 ) and appearance of the university (mean $=3.46$ ). However, the respondents are relatively least likely to be influenced by the class size (e.g. student/teacher ratio) of the university (mean $=3.40$ ) and extra-curricular programmes at the university (mean $=3.30$ ). Across the six $(6)$ statements, the size of the respective standard deviations indicates that these perceptions are consistent.

Table 2: Mean and SD on Institutional Factors

\begin{tabular}{lcc}
\hline \multicolumn{1}{c}{ Statement } & Mean & SD \\
\hline Location of the university influenced me to study music & 3.57 & 1.136 \\
Facilities at the university influenced me to study music & 3.55 & 1.051 \\
$\begin{array}{l}\text { Campus atmosphere influenced me to study music } \\
\text { Appearance of the university influenced me to study music }\end{array}$ & 3.54 & 1.036 \\
$\begin{array}{l}\text { Class size (e.g. student/teacher ratio) of the university influenced } \\
\text { me to study music }\end{array}$ & 3.46 & 1.007 \\
$\begin{array}{l}\text { Extra-curricular programmes at the university influenced me to } \\
\text { study music }\end{array}$ & 3.40 & 1.067 \\
$\quad$ Institutional Factors & 3.30 & 1.115 \\
\hline
\end{tabular}

\section{Perceptions on Financial Factors}

Table 3 shows that on the average, the respondents' score on financial factors related to the choice of music studies is lower (mean $=3.30$ ) compared to institutional factors discussed above. Moreover, respondents are relatively least likely to be influenced by their financial status to study music (mean = 3.17). The financial factor with the highest influence is the cost/ fees of the university (mean $=3.47$ ). This is followed by financial aid/scholarships from the university, and parents' income (mean $=3.33$ and 3.17) respectively. The size of the multiple standard deviations can be explained as the perceptions of the respondents', on average, being mostly consistent across the items.

Table 3: Mean and SD on Financial Factors

\begin{tabular}{lcc}
\hline \multicolumn{1}{c}{ Statement } & Mean & SD \\
\hline Cost/ fees of the university influenced me to study music & 3.47 & 1.127 \\
Financial aid/scholarships from the university influenced me to study & 3.33 & 1.134 \\
music & 3.25 & 1.140 \\
Parents' income influenced me to study music & 3.17 & 1.149 \\
My financial status influenced me to study music & 3.30 & 0.960 \\
\hline
\end{tabular}

$n=489$ 


\section{Perceptions on Personal/Social Factors}

Table 4 presents the mean scores of statements to measure the perceptions of respondents on personal/social factors and its related statistics. Based on all the six statements, the mean score of 3.29 implies that on the average, the respondents' perceptions level for personal/social factors are also moderate. In particularly, respondents are mostly influenced by teachers' and parents' advice to study music (mean $=3.45$ and 3.39 respectively). These are followed by the influence from social network of the university/ faculty (mean $=3.38$ ) and having peers or friends at the university (mean $=3.33$ ). However, they relatively have been less influenced by friends' advice (mean $=3.15$ ) and are less likely to be influenced by the distance of university from home (mean $=3.07)$.

Table 4: Mean and SD on Personal/Social Factors

\begin{tabular}{lcc}
\multicolumn{1}{c}{ Statement } & Mean & SD \\
\hline Teachers' advice influenced me to study music & 3.45 & 1.167 \\
Parents' advice influenced me to study music & 3.39 & 1.208 \\
$\begin{array}{l}\text { Social networking (e.g. Facebook, Twitter. etc.) from the } \\
\text { university/faculty influenced me to study music }\end{array}$ & 3.38 & 1.185 \\
$\begin{array}{l}\text { Having peers or friends at the university influenced me to study } \\
\text { music }\end{array}$ & 3.33 & 1.188 \\
$\begin{array}{l}\text { Friends' advice influenced me to study music } \\
\text { Distance of university from home influenced me to study music }\end{array}$ & 3.15 & 1.183 \\
$\quad$ Personal/Social Factors & 3.07 & 1.264 \\
\hline
\end{tabular}

\section{Differences in Various Factors on Students' Choice of Music Studies (Institutional Factors, Academic Factors, Financial Factors, Personal/ Social Factors) among Universities and Instruments Played by Respondents}

Analysis on the differences on students' choice of music studies between universities attended and instrument played is carried out using One-Way Analysis of Variance (ANOVA) involving the four (4) factors on students' choice of music studies. The results are discussed in the following section.

\section{a) Differences in Various Factors on Students' Choice of Music Studies (Institutional Factors, Academic Factors, Financial Factors, Personal/ Social Factors) among the Universities of Respondents}

The test statistics in Table 5 show that perceptions on choice of music studies differ among respondents of different universities with respect to institutional $F(6,482)=5.443$, academic $F(6,482)=7.432$, financial $F(6,482)=3.026$ and personal/social factors $F(6,482)=4.539$, respectively. Therefore, it can be concluded that the mean scores are different among universities $(p>0.01)$. Following that, a post hoc using Duncan Multiple Range Test (DMRT) was conducted on the significant variable to look for differences between groups.

Table 5: ANOVA Test on the Four Factors among Universities

\begin{tabular}{llllll}
\hline Factors & df & $\boldsymbol{F}$ & SS & MS & Sig \\
\hline Institutional & & & & & $0.000^{*}$ \\
Between Group & 6 & 5.443 & 20.853 & 3.475 & \\
Within Group & 482 & & 307.743 & 0.638 & \\
Academic & & & & & $0.000^{*}$ \\
Between Group & 6 & 7.432 & 20.891 & 3.482 & \\
Within Group & 482 & & 225.820 & 0.469 & \\
Financial & & & & & $0.006^{*}$ \\
\hline
\end{tabular}



DOI: https://doi.org/10.47405/mjssh.v7i1.1241

\begin{tabular}{llllll}
\hline Between Group & 6 & 3.026 & 16.317 & 2.719 & \\
Within Group & 482 & & 433.162 & 0.899 & $0.000^{*}$ \\
Personal/social & & & & & \\
Between Group & 6 & 4.539 & 19.688 & 3.281 & \\
Within Group & 482 & & 348.451 & 0.723 & \\
\hline$* *$ sig at 0.01 & & & & &
\end{tabular}

With regards to institutional factors, the results of DMRT (Table 6) reveal that respondents from UPSI, UNIMAS, UiTM and UMS ( $m=3.74,3.58,3.50$, and 3.49 , respectively) are relatively more likely to have been influenced by the factors to study music than respondents from UM, UPM and USM ( $m=$ $3.24,3.22$, and 3.12 , respectively).

With regards to academic factors, the results of DMRT (Table 7) reveal that respondents from UPSI, UNIMAS, UiTM, UMS, and UPM ( $m=3.87,3.75,3.74,3.67$, and 3.67 , respectively) are relatively the most likely to have been influenced by academic factors to study music, and those from UM and USM $(m=3.46$ and 3.10), are the least likely to be so.

Moreover, from the financial aspect, results from DMRT (Table 8) show that respondents from UiTM, UPM, and UM ( $m=3.58,3.53$, and 3.37, respectively) are relatively the most likely to have been influenced to study music due to financial factors than those from UMS, UNIMAS, UPSI, and USM ( $m$ $=3.22,3.15,3.14$, and 3.12 , respectively).

The results for personal/social factors of DMRT (Table 9) indicate that respondents from UPSI, UMS, UiTM, UNIMAS and UPM $(m=3.50,3.48,3.37,3.29$, and 3.20, respectively) are relatively the most likely to have been influenced to study music because of personal/social factors, and those from USM and UM ( $m=3.01$ and 2.91), are the least likely to be so.

Table 6: DMRT for Institutional Factors

\begin{tabular}{lcccc}
\hline \multicolumn{1}{c}{ Uni } & $\mathbf{N}$ & \multicolumn{2}{c}{ Subset for alpha $=\mathbf{0 . 0 5}$} \\
USM & $\mathbf{N}$ & $\mathbf{1}$ & $\mathbf{2}$ & $\mathbf{3}$ \\
UPM & 39 & 3.1239 & & \\
UM & 60 & 3.2167 & 3.2167 & \\
UMS & 60 & 3.2417 & 3.2417 & \\
UiTM & 60 & & 3.4889 & 3.4889 \\
UNIMAS & 85 & & 3.5000 & 3.5000 \\
UPSI & 78 & & & 3.5855 \\
Sig. & 107 & & & 3.7445 \\
\hline
\end{tabular}

Table 7: DMRT for Academic Factors

\begin{tabular}{llccc} 
& \multicolumn{4}{c}{ Subset for alpha $=\mathbf{0 . 0 5}$} \\
\multicolumn{1}{c}{ Uni } & $\mathbf{N}$ & $\mathbf{1}$ & $\mathbf{2}$ & $\mathbf{3}$ \\
\hline USM & 39 & 3.0983 & & \\
UM & 60 & & 3.4622 & \\
UPM & 60 & & 3.6694 & 3.6694 \\
UMS & 60 & & 3.6722 & 3.6722 \\
UiTM & 85 & & & 3.7431 \\
UNIMAS & 78 & & & 3.7457 \\
\hline
\end{tabular}



DOI: https://doi.org/10.47405/mjssh.v7i1.1241

\begin{tabular}{|c|c|c|c|c|}
\hline UPSI & 107 & & & 3.8785 \\
\hline Sig. & & 1.000 & .102 & .127 \\
\hline
\end{tabular}

Table 8: DMRT for Financial Factors

\begin{tabular}{lcccc} 
& & \multicolumn{2}{c}{ Subset for alpha $=\mathbf{0 . 0 5}$} \\
\multicolumn{1}{c}{ Uni } & $\mathbf{N}$ & $\mathbf{1}$ & $\mathbf{2}$ & $\mathbf{3}$ \\
\hline USM & 39 & 3.1218 & & \\
UPSI & 107 & 3.1433 & & \\
UNIMAS & 78 & 3.1506 & & \\
UMS & 60 & 3.2208 & 3.2208 & \\
UM & 60 & 3.3708 & 3.3708 & 3.3708 \\
UPM & 60 & & 3.5333 & 3.5333 \\
UiTM & 85 & & & 3.5824 \\
Sig. & & .192 & .078 & .237 \\
\hline
\end{tabular}

Table 9: DMRT Test for Personal/Social Factors

\begin{tabular}{lcccc} 
& \multicolumn{4}{c}{ Subset for alpha $=\mathbf{0 . 0 5}$} \\
\multicolumn{1}{c}{ Uni } & $\mathbf{N}$ & $\mathbf{1}$ & $\mathbf{2}$ & $\mathbf{3}$ \\
\hline UM & 60 & 2.9083 & & \\
USM & 39 & 3.0128 & 3.0128 & \\
UPM & 60 & 3.2028 & 3.2028 & 3.2028 \\
UNIMAS & 78 & & 3.2885 & 3.2885 \\
UiTM & 85 & & & 3.3686 \\
UMS & 60 & & & 3.4778 \\
UPSI & 107 & & & .085 \\
Sig. & & .064 & .0831 \\
\hline
\end{tabular}

b) Differences in Various Factors on Students' Choice of Music Studies (Institutional Factors, Academic Factors, Financial Factors and Personal/ Social Factors) among Instruments Played by Respondents

The test statistics shows that there is a statistical difference between institutional $F(5,483)=3.944$ and academic factors $F(5,483)=4.625$ among instruments that the respondents play. It is concluded therefore, that the mean scores on institutional and academic factors differ among the instrument that they play $(p>0.01)$. As a result, a post hoc test was then employed on the significant variable using the Duncan Multiple Range Test (DMRT) to seek differences between groups.

Table 10: ANOVA Test on the Four Factors among Instrument Played

\begin{tabular}{llllll} 
Factors & df & $\boldsymbol{F}$ & SS & MS & Sig \\
\hline Institutional & & & & & $0.002^{*}$ \\
Between Group & 5 & 3.944 & 12.890 & 2.578 & \\
Within Group & 483 & & 328.595 & 0.654 & \\
Academic & & & & & $0.000^{*}$ \\
\hline
\end{tabular}


DOI: https://doi.org/10.47405/mjssh.v7i1.1241

\begin{tabular}{llllll}
\hline Between Group & 5 & 4.625 & 11.273 & 2.255 & \\
Within Group & 483 & & 235.439 & 0.487 & 0.724 \\
Financial & & & & & \\
Between Group & 5 & 0.569 & 2.630 & 0.526 & \\
Within Group & 483 & & 446.849 & 0.925 & \multirow{2}{*}{0.039} \\
Personal/social & & & & & \\
Between Group & 5 & 2.364 & 8.795 & 1.759 & \\
Within Group & 483 & & 359.344 & 0.744 & \\
\hline
\end{tabular}

${ }^{* *}$ sig at 0.01

The results of DMRT (Table 11) indicate that respondents who studied vocal, played brass, string, woodwind and percussion $(m=3.72,3.63,3.54,3.52$, and 3.47 , respectively) are relatively more likely than respondents who played piano $(m=3.27)$ to consider institutional factors as a reason that influence them to study music.

With regards to academic factors, the results of DMRT (Table 12) reveal that respondents who studied vocal, played woodwind, brass, string, and percussion $(m=3.91,3.81,3.76,3.72$, and 3.61, respectively) are relatively the most likely to have been influenced by the academic factors for them to study music, and those who played piano $(m=3.49)$ are the least likely to be so.

However, there is no significant difference between financial and personal/social factors among instruments played $(p>0.01)$. It can be concluded that there is no difference in their agreement level towards financial and personal/social factors between instruments that they play.

Table 11: DMRT for Institutional Factors

\begin{tabular}{lccc} 
& \multicolumn{3}{c}{ Subset for alpha $=\mathbf{0 . 0 5}$} \\
\multicolumn{1}{c}{ Instrument } & $\mathbf{N}$ & $\mathbf{1}$ & $\mathbf{2}$ \\
\hline Piano & 171 & 3.2700 \\
Percussion family & 37 & 3.4730 & 3.4730 \\
Woodwind family & 42 & 3.5198 & 3.5198 \\
String family & 143 & 3.5350 & 3.5350 \\
Brass family & 20 & 3.6333 & 3.6333 \\
Vocal & 76 & & 3.7215 \\
Sig. & & .050 & .188 \\
\hline
\end{tabular}

Table 12: DMRT for Academic Factors

\begin{tabular}{lccc} 
& \multicolumn{3}{c}{ Subset for alpha $=\mathbf{0 . 0 5}$} \\
\multicolumn{1}{c}{ Instrument } & $\mathbf{N}$ & $\mathbf{1}$ & 2 \\
\hline Piano & 171 & 3.4897 & \\
Percussion family & 37 & 3.6126 & 3.6126 \\
String family & 143 & 3.7203 & 3.7203 \\
Brass family & 20 & 3.7583 & 3.7583 \\
Woodwind family & 42 & & 3.8056 \\
Vocal & 76 & & 3.9079 \\
Sig. & & .088 & .067 \\
\hline
\end{tabular}




\section{Differences of Various Factors on Students' Choice of Music Studies (Institutional Factors, Academic Factors, Financial Factors and Personal/ Social Factors) between Ethnicities of Respondents}

Table 13 presents the summary statistics of independent samples $t$-test involving the four (4) various factors on students' choice of music studies to determine whether perceptions on these differ between ethnicities of the respondents.

The mean scores of institutional, academic, and personal/social factors are statistically difference at 0.01 $(p<0.01)$. Hence, it is concluded that mean scores on institutional, academic, and personal/social factors differ between their ethnicity (Bumiputera or non-Bumiputera). It can be seen that for all the three dimensions, Bumiputera respondents had agreed more towards institutional $(m=3.65)$, academic $(m=$ $3.80)$, and personal/social factors $(m=3.47)$, compared to non-Bumiputera respondents $(m=3.16,3.44$, 2.99 , respectively). However, there is no significant difference in financial factors between Bumiputera and non-Bumiputera $(p>0.05)$. It can be concluded that there is no difference in their agreement level towards financial factors - for both Bumiputera and non-Bumiputera, their agreement level is almost the same.

Table 13: $t$-test on the Four Factors between Ethnicities

\begin{tabular}{lcccc}
\hline \multicolumn{1}{c}{ Factors } & Ethnicities & Mean & $\boldsymbol{t}$-value & $\boldsymbol{p}$-value \\
\hline \multirow{2}{*}{ Institutional } & Bumiputera & 3.65 & \multirow{2}{*}{6.541} & $0.000^{* *}$ \\
& Non-Bumiputera & 3.16 & & \\
Academic & Bumiputera & 3.80 & 5.521 & $0.000^{* *}$ \\
\multirow{2}{*}{ Financial } & Non-Bumiputera & 3.44 & & \\
& Bumiputera & 3.30 & -0.091 & 0.927 \\
\multirow{2}{*}{ Personal/social } & Non-Bumiputera & 3.31 & & \multirow{2}{*}{$0.000^{* *}$} \\
& Bumiputera & 3.47 & 6.502 & \multirow{2}{*}{} \\
\end{tabular}

** sig at 0.01

\section{Conclusion}

This study has presented the findings of factors influencing choice of music studies among undergraduate music students in Malaysian public universities. The study found that on the choice of music study, academic factors is the most influential, followed by institutional factors, financial factors and lastly personal/ social factors in that order.

This study is in line with Cabrera and La Nasa (2000), Filter (2010), and Yoo (2020). Financial assistance and understanding of the financial procedure had influenced parents and students to attend to an affordable university (Cabrera \& La Nasa, 2000). In today's economy where many things are at stake, some cannot afford spending too much on education - tertiary education itself is already expensive but a music degree can be quite costly. On the other hand, institutional factors are more likely to influence students where the distance to the university can play a role in their decisionmaking. Students were less likely to enrol at their first-choice university as the distance between them and the institution increased (Filter, 2010). This could be because they would like to be near to home and to also reduce the cost of transportation and accommodation. Moreover, students are prone to be affected by the value of music and the attitude they carry towards music when choosing music. Furthermore, teachers played an important role in creating a pleasant and meaningful classroom atmosphere (Yoo, 2020). Since the learning process is mainly centred on the instructor or teacher, the students might consider this an important factor in choosing their major.

Regarding the differences on factors influencing students' choice of music studies with selected demographic profiles, results show that there are differences in the perceptions among undergraduate 
music students between universities they attended and the instrument they played. However, two other factors of music studies which are financial and personal/social factors did not show any difference between instruments played.

Results also show that there are differences in various factors on choice of music studies between ethnicities on academic, institutional and personal/social factors. However, financial factors did not show any difference in choice of music studies. Mean scores for academic, institutional and personal/social factors for Bumiputera respondents were significantly higher than non-Bumiputera counterpart.

This study has dealt concerning the area of interest on factors that influenced the choice of music studies among undergraduate music students in Malaysian public universities. The current study will at least fill the gap in the literature and develop the foundation for related research in the future. It has shed light regarding the choice of music studies and provide teachers or lecturers with relevant data regarding the various variables namely academic factors, institutional factors, financial factors, and personal/ social factors. With the findings found in this study, hopefully the knowledge on factors influencing the choice of music studies among students who are pursuing their career life after they graduated from universities will be increased.

\section{Acknowledgement}

The researchers wish to thank all respondents who had participated in this survey.

\section{References}

Cabrera, A., \& La Nasa, S. (2000). Understanding the college-choice process. New Directions for Institutional Research, 2000(107), 5-22.

Constantine, M. E. (2011). The High School Musical Experiences of College Students. Doctoral dissertation, Case Western Reserve University.

Curtis, R. (2012). Factors Influencing the College Choice of Music Majors Attending A Four-Year Institution: A Comparative Study. Doctoral dissertation, Lindenwood University.

Filter, S. (2010). The Choice-of-College Decision of Academically Talented Students. Doctoral dissertation, The George Washington University.

Gillespie, R. \& Hamann, D. L. (1999). Career choice among string music education students in American colleges and universities. Journal of Research in Music Education, 47(3), 266-278.

Hamilton, A. T. (2016). Factors that lead students to study music education: A descriptive study. Master thesis, University of Louisville.

Jones, M. O. (1964). Factors Influencing Students in the Choice of Music as A Career. Doctoral dissertation, Florida State University.

Kelly, S. (1988). Marketing your college music program to students. Music Educators Journal, 75(3), 27-29.

Klinedinst, R. (1991). Predicting performance achievement and retention of fifth-grade instrumental students. Journal of Research in Music Education, 39(3), 225-238. https://doi. org/10.2307/3344722.

Locke, J. (1982). Influences on the College Choice of Freshman Music Majors in Illinois. Doctoral dissertation, University of Illinois.

Lindeman, C. A. (2004). Ten strategies for higher education and the k-12 music teacher shortage. Music Educators Journal, 90(3), 66.

Ludeman, V. L. (1964). Contributing Factors in the Selection of College or University By Freshman Music Majors. Doctoral dissertation, Colorado State University.

Madsen, C. K., \& Kelly, S. N. (2002). First remembrances of wanting to become a music teacher. Journal of Research in Music Education, 50(4), 323-332. 
McCarthy, C., O'Flaherty, J., \& Downey, J. (2019). Choosing to study music: student attitudes towards the subject of music in second-level education in the Republic of Ireland. British Journal of Music Education, 36(2), 139-153.

McClellan, E. R. (2007). Relationships Among Parental Influences, Selected Demographic Factors, Adolescent Self-Concept as A Future Music Educator, and The Decision to Major in Music Education. Doctoral dissertation, University of North Carolina, Greensboro.

McClellan, E. R. (2011). Relationships among parental influences, selected demographic factors, adolescent self-concept as a future music educator, and the decision to major in music education. Bulletin of the Council for Research in Music Education, 187, 49-64.

Mizener, C. P. (1993). Attitudes of children toward singing and choir participation and assessed singing skill. Journal of Research in Music Education, 41(3), 233-245. https://doi. org/10.2307/3345327

Nor, M. M. (2011). Developing human capital through music education in Malaysia. Academic Research International, 1(2), 220.

Overmier, R. D. (2003). Recognizing the choices of freshman music majors. Paper presented at the Hawaii International Conference on Arts and Humanities, Honolulu, HI.

Sichivitsa, V. O. (2007). The Influences of parents, teachers, peers and other factors on students' motivation in music. Research Studies in Music Education, 29(1), 55-68.

Thornton, L., \& Bergee, M. (2008). Career choice influences among music education students at major schools of music. Bulletin of the Council for Research in Music Education, 177, 7- 17.

Yoo, H. (2020). Factors influencing future music participation: A review of literature Based on the Theory of Planned Behavior. National Association for Music Education. 